\title{
Synthesis of Manganese Oxide Octahedral Molecular Sieves \\ Containing Cobalt, Nickel, or Magnesium, and the Catalytic Properties for Hydration of Acrylonitrile
}

\author{
Ayumu Onda*, Sayuri Hara, Koji Kajiyoshi, and Kazumichi Yanagisawa \\ Research Laboratory of Hydrothermal Chemistry, Faculty of Science, Kochi \\ University, 2-17-47 Asakurahoncho, Kochi 780-8073 Japan.
}

*CORRESPONDING AUTHOR

Tel: +81-88-844-5353. FAX: +81-88-844-8362. E-mail: onda@cc.kochi-u.ac.jp. 


\begin{abstract}
An octahedral molecular sieve known as OMS-1 has todorokite structure composed of magnesium and manganese oxides, which was named as Mg-todorokite here. Octahedral molecular sieves containing cobalt (Co-todorokite) or nickel (Ni-todorokite) without magnesium were prepared by a sequential method under optimum conditions and compared with the Mg-todorokite by powder XRD, ICP, FESEM, and catalytic reactions. The compositions of Co-todorokite, Ni-todorokite, and $\mathrm{Mg}$-todorokite are $\mathrm{Co}_{0.37} \mathrm{MnO}_{2.3}\left(\mathrm{H}_{2} \mathrm{O}\right)_{2.1}$, $\mathrm{Ni}_{0.24} \mathrm{MnO}_{2.0}\left(\mathrm{H}_{2} \mathrm{O}\right)_{2.1}$, and $\mathrm{Mg}_{0.22} \mathrm{MnO}_{2.0}\left(\mathrm{H}_{2} \mathrm{O}\right)_{2.2}$, respectively. The Co-todorokite and Ni-todorokite are comparable in crystallinity with the highly crystalline Mg-todorokite. The catalytic properties were examined for the hydration of acrylonitrile. The apparent activation energies depend on the foreign metals. The order is Co-todorokite $<$ Ni-todorokite $<$ Mg-todorokite. The four products of the Mg-todorokite catalysis are 3-hydroxy-propionitrile, and bis-2-cyano-ethylether, succinonitrile, and acrylamide. The acid-treatments for Mg-todorokite suppress the formations of 3-hydroxy-propionitrile and bis-2-cyano-ethylether, which would be due to the weakening of the basicity with the removal of magnesium ions. The only product of the Co-todorokite and the Ni-todorokite catalysis is acrylamide because of not containing magnesium.
\end{abstract}

5 Key words; todorokite; octahedral molecular sieves, manganese oxides; catalysts; acrylonitrile hydration 


\section{Introduction}

Todorokite-type manganese oxide is one of the materials with edge- and corner-shared $\mathrm{MnO}_{6}$ octahedra that form one-dimensional tunnel structures of various sizes, and it has tunnels of a $(3 \times 3)$ framework structure [1-4]. The framework is composed mainly of $\mathrm{Mn}(4+) \mathrm{O}_{6}$ octahedra. However, some of the central ions of the octahedra are trivalent and/or divalent manganese ions and foreign metal ions. Therefore, it has cation sites [3]. It was reported that some metal cations not only exist at cation sites but also are incorporated into the framework by isomorphous substitutions for parts of the skeletal $\mathrm{MnO}_{6}$ octahedra in layered and tunnel manganese oxides $[3,5,6]$.

Naturally occurring todorokite and todorokite-like manganese oxides include some inorganic cations, such as calcium, magnesium, and sodium, although their cation content differs from one locality to another [7-9]. Although todorokite in the natural form is a hydrated manganese oxide with impurities, the todorokite-type manganese oxide has been synthesized hydrothermally as a single-phase material [10-13]. Golden et al. have reported a synthetic todorokite-type manganese oxide that was prepared by the hydrothermal treatment of $\mathrm{Mg}^{2+}$-exchanged birnessite-type manganese oxide [10]. Shen et al. have developed a thermally stable todorokite-type manganese oxide containing magnesium, called OMS-1, and found that it can be used as a molecular sieve with a pore size of $0.69 \mathrm{~nm}$ estimated by adsorption of various kinds of organic compounds [11].

These materials have many applications, such as ion sieves [4], cathodic materials for batteries [14-16], and as catalysts [17-26]. Todorokite and todorokite-like manganese oxides are expected to have unique catalytic properties because of the manganese oxide framework, cations, and the tunnel opening [9, 10]. Some promising examples are the oxidations of carbon monoxide $[17,18]$, alcohols $[19,20]$ and hydrocarbons [21-24], the decomposition of hydrogen peroxide [25], and the cracking of propane [26].

Manganese dioxide shows good catalytic activity not only for the oxidation reactions but also for hydration reactions [27-30]. As shown in Scheme 1, the hydration of acrylonitrile can result in two products, acrylamide via hydration of $\mathrm{C} \equiv \mathrm{N}$ bonds in the 1,2 addition, and 3-hydroxy-propionitrile and its derivatives via hydration of $\mathrm{C}=\mathrm{C}$ double bonds in the 1,4 addition [28]. It was interesting to note the activity and the selectivity of todorokite catalysts for the hydration. 


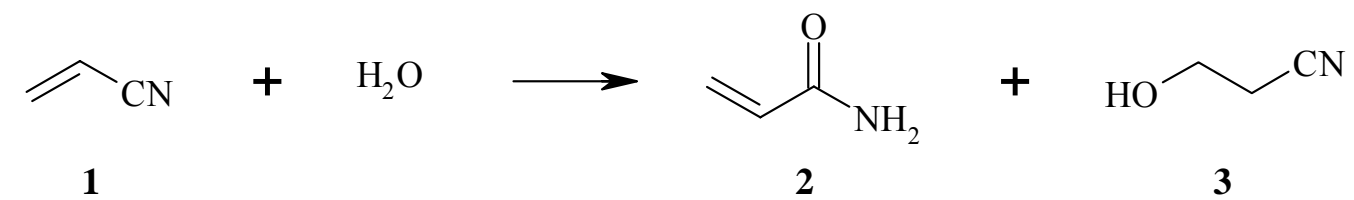

Scheme 1. The hydration of acrylonitrile: 1, acrylonitrile; 2, acrylamide; 3, 3-hydroxy-propionitrile.

In the last two decades, there have been many reports of todorokite-type octahedral molecular sieves prepared by using magnesium salts and/or $\mathrm{Mg}\left(\mathrm{MnO}_{4}\right)_{2}$ [2, 10-12]. Some of divalent magnesium cations exist in the framework and play a role in maintaining the stable structure of these manganese oxide compounds [31]. However, the todorokite catalysts with magnesium ions can result in undesired by-products for some reactions because of the base catalysis of magnesium species. On the other hands, there have been few reports of synthetic todorokite samples not containing magnesium $[5,32]$, whose catalytic properties were not reported. For the development of todorokite catalysts, it is required the synthesis of crystalline todorokites containing the other metal ions from magnesium and the clarification of catalytic properties of the todorokites.

Here in, we report the synthesis of Co-todorokite and Ni-todorokite comparable in crystallinity to the highly crystalline Mg-todorokite, and, for the first time, the catalysis for the hydration of acrylonitrile. The effects of cobalt and nickel ions on the formation of todorokite and the catalytic properties are compared to those of magnesium ions by characterizations of the powder X-ray diffraction patterns, ICP elemental analysis, Mn average oxidation state determinations, and field emission scanning electron microscopy (FESEM) observations and the catalytic reactions.

\section{Experimental}

\subsection{Synthesis procedure}

Synthesis of todorokite-type manganese oxides containing a "foreign cation" $\mathrm{Co}^{2+}, \mathrm{Ni}^{2+}$, or $\mathrm{Mg}^{2+}$, involved three major steps, as shown in Figure $1[11,33]$. (1) Synthesis of the layered precursor, birnessite, by the slow addition of a homogeneously mixed solution of divalent manganese ions and foreign divalent metal ions into an alkali solution including heptavalent manganese ions, and by aging under alkaline conditions. (2) Ion-exchange with a solution of the same foreign cation to expand the interlayer distance of the layered precursor. (3) Transformation of the layered precursor to the todorokite-type manganese oxide under 
hydrothermal conditions. The todorokite is referred to as M-todorokite, where $\mathrm{M}$ represents a foreign cation doped in the synthesis of birnessite samples and in the ion-exchange steps.

The typical synthesis of Ni-todorokite was as follows. These chemicals were purchased from Wako Pure Chemical Industries. Firstly, solution A $\left(\mathrm{Ni}\left(\mathrm{NO}_{3}\right)_{2} \cdot 6 \mathrm{H}_{2} \mathrm{O}(1.87 \mathrm{~g}, 6.43 \mathrm{mmol})\right.$ and $\mathrm{MnCl}_{2} \cdot 4 \mathrm{H}_{2} \mathrm{O}(6.37 \mathrm{~g}, 32.2$ mmol) in $100 \mathrm{ml}$ of distilled deionized water (DDW)) was added dropwise over a period of 10 min with vigorous stirring at room temperature $(\sim 296 \mathrm{~K})$ into solution $\mathrm{B}\left(\mathrm{KMnO}_{4}(2.02 \mathrm{~g}, 12.8 \mathrm{mmol})\right.$ and $\mathrm{NaOH}(36$ $\mathrm{g}, 0.90 \mathrm{~mol}$ ) in $100 \mathrm{ml}$ of DDW). After the solutions were mixed, they were stirred for a total of $30 \mathrm{~min}$. The suspension was aged at room temperature for $24 \mathrm{~h}$, and it was filtered and washed with DDW until the $\mathrm{pH}$ was about 7. The resultant shiny sample was a layered birnessite material, referred to as Na-(Ni)-birnessite. Most cations at the cation sites in interlayers are sodium ions. Secondly, the Na-(Ni)-birnessite was ion-exchanged with $200 \mathrm{ml}$ of a $0.1 \mathrm{~mol} \mathrm{~L}^{-1} \mathrm{Ni}\left(\mathrm{NO}_{3}\right)_{2}$ aqueous solution at room temperature for $24 \mathrm{~h}$. The ion-exchange expanded the interlayer distance. The resultant layered sample was washed and filtered ten times with $200 \mathrm{ml}$ of DDW and is referred to as Ni-buserite. Thirdly, it was treated under hydrothermal conditions ( $433 \mathrm{~K}$ for $48 \mathrm{~h}$ in an autoclave lined with Teflon) and the resultant solid was washed and filtered with DDW, and dried at $333 \mathrm{~K}$ to yield Ni-todorokite.

\subsection{Characterization}

The crystal structure of all samples dried at $333 \mathrm{~K}$ over night was investigated by powder X-ray diffraction (XRD; Rigaku Rotaflex RAD-RC) with a $\mathrm{CuK} \alpha$ radiation source. Elemental analysis of the samples was done by inductively coupled plasma (ICP; Seiko SPS7000A). Approximately $10 \mathrm{mg}$ of sample was dissolved in $5 \mathrm{ml}$ of aqua regia, and then diluted to $50 \mathrm{ml}$ with DDW. All samples were analyzed for $\mathrm{K}, \mathrm{Na}, \mathrm{Mn}, \mathrm{Ni}$, $\mathrm{Co}$, and $\mathrm{Mg}$. The average oxidation state (AOS) of manganese in the samples was determined by permanganate titration with sodium oxalate. The prepared samples and the commercial $\mathrm{MnO}$ and $\mathrm{Mn}_{2} \mathrm{O}_{3}$ (Aldrich Chemicals, 99\%) and $\mathrm{MnO}_{2}$ (Wako Pure Chemicals, 99.5\%) powders used as standard samples were dried overnight at $333 \mathrm{~K}$ and cooled to room temperature in a desiccator. The morphology of samples was observed by field emission scanning electron microscopy (FESEM) with a JEOL JSM-6500F instrument. The sample (dried overnight at $333 \mathrm{~K}$ ) was mounted on an aluminum holder and platinum-coated by a deposition apparatus (Hitachi E102 ION SPUTTER) to minimize charging. 


\subsection{Catalytic reaction}

The hydration reactions of acrylonitrile took place in a Teflon-lined autoclave with an inner volume of 5 $\mathrm{ml}$. The $2.8 \mathrm{mmol}$ of acrylonitrile was introduced into the vessel with $3 \mathrm{ml}$ of DDW and $50 \mathrm{mg}$ of catalyst that had been air-dried overnight at $333 \mathrm{~K}$. The reaction was typically carried out at $393 \mathrm{~K}$ for $3 \mathrm{~h}$. The autoclave contents were stirred by rotation during the reaction $(25 \mathrm{rpm})$. The prepared todorokite, $\mathrm{MnO}_{2}$, $\mathrm{NiO}$ and $\mathrm{CoO}$ (Wako pure chemicals, 99\%), $\mathrm{MgO}$ (Ube Materials, 99\%), $\mathrm{Mn}_{3} \mathrm{O}_{4}$ (Aldrich Chemicals, 97\%), $\mathrm{MnO}$, and $\mathrm{Mn}_{2} \mathrm{O}_{3}$ powders were dried overnight at $353 \mathrm{~K}$ and cooled to room temperature in a desiccator before the catalytic reactions.

\subsection{Product analysis}

At the end of the reaction time, the autoclave was cooled to room temperature. The solution with the catalyst was removed from the autoclave and separated in a rotating separator. The supernatant liquid was analyzed by GC-MS (Hewlett-Packard, HP5890 and HP5972) with a capillary column (HP-PLOTQ, 30 m, $0.25 \mathrm{~mm}$ i.d.). The elution of metal cations into a water solvent was detected by ICP.

\section{Results and Discussion}

\subsection{Preparation and characterization of Ni-todorokite, Co-todorokite, and Mg-todorokite samples}

\subsubsection{Preparation of octahedral molecular sieves}

The preparations of octahedral molecular sieves (Ni-todorokite, Co-todorokite, and Mg-todorokite) were examined for a sequential method illustrated by Figure 1. The Mg-todorokite prepared under the conditions given in Table 1 had large powder volumes after drying at $333 \mathrm{~K}$. The XRD pattern is shown in Figure 2a. The main diffraction peaks appeared at $0.958 \mathrm{~nm}, 0.476 \mathrm{~nm}$, and $0.318 \mathrm{~nm}$. The all diffraction peaks for Mg-todorokite sample was attributed to the todorokite phase of PDF card \#38-475 [34] of natural todorokite and data reported for synthesized todorokite samples $[11,12]$, except for a peak of manganite at $0.340 \mathrm{~nm}$. In Figure 3, Mg-todorokite contains both needle and platelet shaped crystallites. The XRD pattern and SEM image showed a highly crystalline todorokite structure.

On the other hands, when todorokite samples containing nickel and cobalt were prepared under the conditions used for Mg-todorokite (Table 1), both of their XRD patterns showed broader peaks with much lower intensity at $2 \theta$ angles attributed to the todorokite phase than that of Mg-todorokite. The aggregates of 
small particles were observed in their SEM images. Examining the synthesis parameters described in Table 1, the crystallinities and crystallite sizes of synthetic todorokite-type manganese oxides containing cobalt (Co-todorokite) and nickel (Ni-todorokite) significantly depended on the concentrations of sodium hydroxide and the aging time in birnessite synthesis, which suggested that the regularity of atomic arrangements of the birnessite precursor might affect the crystallinity of todorokite-type octahedral molecular sieves and might be inhibited by the addition of nickel and cobalt ions.

Both of the Ni-todorokite and Co-todorokite prepared under the conditions given in Table 1 had also large powder volumes. As shown in Figure 2, the main diffraction peaks appeared at $0.956 \mathrm{~nm}, 0.475 \mathrm{~nm}$, and $0.317 \mathrm{~nm}$ for Ni-todorokite, and at $0.956 \mathrm{~nm}$ and $0.473 \mathrm{~nm}$ for Co-todorokite. Some natural and synthesis todorokites also show major diffraction peaks at $0.95-0.96 \mathrm{~nm}, 0.47-0.48 \mathrm{~nm}$, and $0.32 \mathrm{~nm}$, which were indexed to the $(001) /(100),(002) /(200)$, and $(003) /(300)$ reflections of todorokite structure, respectively [11, 12, 34]. The all diffraction peaks for Ni-todorokite samples were attributed to the todorokite phase. The XRD pattern of the Co-todorokite sample was composed of a major todorokite phase and a minor $\mathrm{Mn}_{2} \mathrm{O}_{3}$ phase. The intensity of the highest diffraction peaks around $0.475 \mathrm{~nm}$ in the XRD patterns of the three todorokite samples was almost the same, which would suggest the crystallinity of Ni-todorokite and Co-todorokite was as high as that of Mg-todorokite.

SEM images of Co-todorokite, Ni-todorokite, and Mg-todorokite are clearly shown in Figure 3. Ni-todorokite and Co-todorokite also contains both platelet and needle shaped crystallites, although the proportions of needle shaped crystals in Ni- and Co-todorokite samples are less than that in Mg-totodorokite. Relative XRD-main peak heights would indicate growth direction of todorokite, however, the needle and platelet shaped morphology seemed not to be reflected in the XRD results. It is not clear what causes little difference in the intensity of diffraction peaks, however similar observations have been observed for M-OMS-1 ( $\mathrm{M}=\mathrm{Co}, \mathrm{Cu}, \mathrm{Mg}, \mathrm{Ni}$, and $\mathrm{Zn})$ prepared by using $\mathrm{Mg}\left(\mathrm{MnO}_{4}\right)_{2}$ [12]. It might be due to very low intensity of the diffraction peaks involving the b-axis direction. The crystals of Ni-todorokite and Co-todorokite are well shaped with a size of about 1-5 $\mu \mathrm{m}$ and about 0.3-2 $\mu \mathrm{m}$, respectively. Specific surface area of Mg-todorokite, Ni-todorokite, and Co-todorokite were 22, 16, and $26 \mathrm{~m}^{2} \mathrm{~g}^{-1}$, respectively, as shown in Table 3.

In consequence, the SEM and XRD measurements revealed that the crystallinities of Ni-todorokite and Co-todorokite prepared under the conditions given in Table 1 were comparable in crystallinity to the highly 
crystalline Mg-todorokite. The morphology and size of crystals depended on the foreign metals which might affect the crystal growth processes.

\subsubsection{Identification of todorokite structure by the heating method}

The diffraction peaks around $1 \mathrm{~nm}$ for todorokite samples were $0.958-0.956 \mathrm{~nm}$ and those for buserite were $0.980-0.977 \mathrm{~nm}$ as shown in Figure 4. Buserite is a precursor just before the hydrothermal treatment (Figure 1). The peak shifts might be due to a constriction by the dehydration in the reconstruction from buserite to todorokite and could distinguish the todorokite samples from the buserite precursors. However, it is generally difficult to distinguish natural todorokite from natural buserite by the powder XRD patterns because of the low degree of crystallinity. The conventional identification of todorokite in the mineralogy field has been XRD measurements after heating samples at about $390 \mathrm{~K}$ [9]. The buserite materials are less thermally stable than todorokite materials.

Before heating, the diffraction peaks of buserite and todorokite samples were clearly sharp as shown in Figure 2 and Figure 4, respectively. After heating at $473 \mathrm{~K}$ for $1 \mathrm{~h}$, the obtained todorokite samples and buserite precursors were analyzed by powder XRD. As shown in Figure 5, all heated buserite precursors had a basal spacing of $0.7 \mathrm{~nm}$ which implied the transformation into the birnessite phase, and any diffraction intensities decreased dramatically. In contrast, all heated todorokite samples clearly showed diffraction peaks at about $0.96 \mathrm{~nm}$ and $0.47 \mathrm{~nm}$, although a slightly broadened line-width and decreasing intensity of the diffraction peaks were observed. It was confirmed that Ni-todorokite, Co-todorokite, and Mg-todorokite samples obtained after the hydrothermal treatment were todorokite-type manganese oxides. In addition, it appears that the Ni-todorokite and the Co-todorokite have relatively low thermal stability, comparing these diffraction intensities at $0.96 \mathrm{~nm}$ with that of the Mg-todorokite after heating at $473 \mathrm{~K}$.

\subsubsection{The chemical composition and the average oxidation states of manganese}

Metal elemental ratios and average oxidation states (AOSs) of manganese in the precursors (birnessite and buserite) and todorokite samples are summarized in Table 2. For all birnessite precursors, the specific molar ratios of $\mathrm{Na} / \mathrm{M} / \mathrm{Mn}$ (where $\mathrm{M}$ is $\mathrm{Mg}, \mathrm{Ni}$, or $\mathrm{Co}$ ) were about $18 / 11 / 71$, and the AOSs of manganese were 3.5-3.6. The M / Mn ratios were almost the same as those in the mother solutions.

The specific molar ratios of $\mathrm{Na} / \mathrm{M} / \mathrm{Mn}$ and the AOSs of manganese in Ni-buserite were $0 / 20 / 80$ and 
3.5, which were almost the same as those in Mg-buserite. In contrast, those in Co-buserite were $0 / 28 / 72$ and 3.8, a significantly high cobalt concentration and a high average oxidation number. The specific molar ratios and the AOSs of manganese in all todorokite samples were almost the same as those in the corresponding buserite samples. The AOSs of manganese of Co-todorokite, Ni-todorokite, and Mg-todorokite are 3.8, 3.6, and 3.6, respectively. The AOSs for todorokites were in the region of reported values [11-14]. The compositions of Co-todorokite, Ni-todorokite, and Mg-todorokite were estimated by the ICP and AOS measurements as $\mathrm{Co}_{0.37} \mathrm{MnO}_{2.3}\left(\mathrm{H}_{2} \mathrm{O}\right)_{2.1}, \mathrm{Ni}_{0.24} \mathrm{MnO}_{2.0}\left(\mathrm{H}_{2} \mathrm{O}\right)_{2.1}$, and $\mathrm{Mg}_{0.22} \mathrm{MnO}_{2.0}\left(\mathrm{H}_{2} \mathrm{O}\right)_{2.2}$, respectively.

During the ion-exchange step, the amounts of introduced cobalt ions were much greater than those of nickel and magnesium ions. Simultaneously, the corresponding amounts of manganese ions were eluted from the layered manganese oxide by the ion-exchange with cobalt ions. It was considered that cobalt ions were exchanged for sodium ions at cation sites and also probably replaced some manganese ions composing the birnessite-type manganese oxide. The oxidation states of dissolved manganese species must be mainly 3 or 2 (less than 4) because the AOS increased after ion-exchange. Some of the dissolved manganese species might form $\mathrm{Mn}_{2} \mathrm{O}_{3}$ as shown in Figure 2c. The easy substitution of cobalt ions might be due to the red-ox property of cobalt ions. The similar ion radius of cobalt to those of divalent and trivalent manganese ions also could be the cause. The ion radii of octahedrally-coordinated cations are: $\mathrm{Mn}^{2+}, 0.67 ; \mathrm{Mn}^{3+}, 0.65 ; \mathrm{Mn}^{4+}, 0.53 ; \mathrm{Mg}^{2+}$, $0.72 ; \mathrm{Ni}^{2+}, 0.69 ;$ and $\mathrm{Co}^{2+}, 0.65 \mathrm{~nm}$.

\subsection{Hydration of acrylonitrile}

The hydration of acrylonitrile was carried out over the synthetic todorokite catalysts and metal oxide catalysts. No elution of metal species from todorokite catalysts was observed by ICP.

\subsubsection{Apparent activation energies for the hydration of acrylonitrile}

In Table 3, the conversion and selectivity for the hydration of acrylonitrile over various catalysts are presented in mol\%. The reactions without catalysts or with solid acid catalysts such as $\mathrm{SiO}_{2}-\mathrm{Al}_{2} \mathrm{O}_{3}$ and H-ZSM-5 resulted in no conversion of acrylonitrile. The todorokite catalysts showed significant catalytic activities for the hydration. The surface density of manganese (and foreign metal) octahedra on the (100) and (001) faces, which are walls of todorokite shown in Figure 1, is estimated to be about $0.018 \mathrm{mmol} \mathrm{m}^{-2}$ from 
lattice parameters of the present data and the JCPDS card (\#38-475). The surface densities of manganese (and foreign metal) on the other faces are less than $0.018 \mathrm{mmol} \mathrm{m}^{-2}$. Assuming that the active sites were surface manganese and foreign metal atoms and adapting data in Table 3, the Co-todorokite catalyst showed a turnover number (TON; mol of product per mol of surface metal contents) of 15 or more. When the reaction time extended to be $6 \mathrm{~h}$, the TON also almost doubled. With these considerations, the hydration of acrylonitrile would proceed catalytically.

In Figure 6, the logarithms of initial reaction rates $\left(r_{0}\right)$ for the acrylonitrile hydration over synthetic todorokite catalysts are plotted against the inverse of reaction temperature. The initial reaction rate was estimated by the initial conversion rate of acrylonitrile. The reaction rate over a manganese dioxide catalyst was assumed to be the first order to the concentration of acrylonitrile and the zeroth order to that of water because of the large excess in the aqueous phase [28]. The selectivity of todorokite catalysts was changed very little at reaction temperatures in the range of 343-433 K. The apparent activation energies of todorokite catalysts were estimated from the slope of an Arrhenius plot as follows; Co-todorokite (39) $>$ Ni-todorokite (57) $>$ Mg-todorokite (104). The values in parentheses are the apparent activation energies in $\mathrm{kJ} \mathrm{mol}^{-1}$. The apparent activation energies of todorokite catalysts depended on the foreign metal elements, which suggested that some parts of foreign metal species compose the surface active sites. Although the Co-todorokite contained a minor $\mathrm{Mn}_{2} \mathrm{O}_{3}$ phase in the XRD pattern (Figure 2), the catalysis of $\mathrm{Mn}_{2} \mathrm{O}_{3}$ would be negligible because of the very low activity of commercial $\mathrm{Mn}_{2} \mathrm{O}_{3}$ powders as shown in Table 3 . The Co-todorokite catalyst showed a relatively low activation energy, which might be due to the AOS value of manganese being 3.8 and/or the interaction of cobalt species with manganese species.

\subsubsection{Selectivities for the hydration of acrylonitrile}

The Co-todorokite and the Ni-todorokite catalysts showed almost $100 \%$ selectivity for acrylamide which was formed via the hydration of the cyano group in the 1,2-addition. Both acrylamide and 3-hydroxy-propionitrile was formed over $\mathrm{CoO}$ and $\mathrm{NiO}$ catalysts. The catalytic selectivity of Ni-todorokite and Co-todorokite was different from those of oxides of cobalt and nickel, which would indicate no particles of these amorphous oxides on these todorokites. The $\mathrm{MnO}_{2}$ catalyst, which showed a broad $\beta-\mathrm{MnO}_{2}$ phase in the XRD pattern, also showed almost $100 \%$ selectivity for acrylamide; however, the apparent activation energy was $43 \mathrm{~kJ} \mathrm{~mol}^{-1}$ and was between those of the Co-todorokite and the Ni-todorokite catalysts. 
On the other hand, 3-hydroxy-propionitrile, which was formed via the hydration of the $\mathrm{C}=\mathrm{C}$ double bond in the 1,4 addition, was a major product over the Mg-todorokite catalyst. The other products were acrylamide, bis-2-cyanoethylether, and succinonitrile. The $\mathrm{MgO}$ catalyst showed high selectivity for 3-hydroxy-propionitrile and bis-2-cyanoethylether, and a trace of succinonitrile and acrylamide. Succinonitrile would be formed over a unique basic active site of the Mg-todorokite catalyst.

The scheme of the hydration of acrylonitrile is shown as Scheme 2. The selectivity might depend on the basicity of catalysts. The 3-hydroxy-propionitrile and bis-2-cyanoethylether are formed via the 1,4 addition probably over relatively strong basic sites which are involved in $\mathrm{MgO}, \mathrm{NiO}, \mathrm{CoO}$, and Mg-todorokite. Acrylamide are formed via the 1,2-addition probably over relatively weak basic sites which are involved in $\mathrm{MnO}_{2}, \mathrm{NiO}, \mathrm{CoO}$, and $\mathrm{Mg}$-, $\mathrm{Ni}$-, and Co-todorokites.

\subsection{The catalytic properties of the acid-treated Mg-todorokite}

The Mg-todorokite was treated in $0.10 \mathrm{~mol} \mathrm{~L}^{-1}$ and $0.010 \mathrm{~mol} \mathrm{~L}^{-1}$ acetic acid solutions for $24 \mathrm{~h}$ at room temperature. The elemental ratios of magnesium to manganese in Mg-todorokite sample decreased with increasing concentration of acetic acid, as shown in Table 4. Magnesium ions were dissolved, but no manganese ion was detected in the filtered solution by ICP. Hydrogen ions might replace magnesium ions at the cation sites. These samples retained the todorokite structure, according to the XRD patterns. They were used as catalysts for the acrylonitrile hydration. The results are shown in Table 4 . The conversions over catalysts after the treatment with acetic acid were almost the same as those before the acid treatment. Over

the Mg-todorokite catalyst treated by a $0.01 \mathrm{~mol} \mathrm{~L}^{-1}$ acetic acid solution, the selectivity of bis-2-cyanoethylether was almost zero and the selectivity of acrylamide was higher than that of 3-hydroxy-propionitrile. Over the Mg-todorokite catalyst treated by a $0.1 \mathrm{~mol} \mathrm{~L}^{-1}$ of acetic acid solution, the selectivity of 3-hydroxy-propionitrile decreased to zero and the selectivity of acrylamide increased. Over both catalysts, the selectivity of succinonitrile increased a little. Although succinonitrile would be formed together with a $\mathrm{C}_{2} \mathrm{H}_{2}$ fragment from two acetonitrile molecules, the gas collected after reaction over the Mg-todorokite did not include acetylene but include a small amount of benzene, which might be formed via the $\mathrm{C}_{2} \mathrm{H}_{2}$ fragment, in the GC-MS measurement. 
The basic active sites producing succinonitorile were not affected by the acid treatments. Because the magnesium ions at cation sites could be preferentially removed by the acid treatments, the undissolved magnesium ions might be in the framework. It was considered that magnesium ions at cation sites might compose the active site for hydration of $\mathrm{C}=\mathrm{C}$ bonds and the undissolved magnesium ions in the framework might compose the active site for the formation of succinonitrile.

In consequence, the catalytic properties of todorokite catalysts depend on the foreign metals and could be affected by the basicities and the average oxidation states of manganese. The Mg-todorokite catalyst has three kinds of active sites which are the weak basic sites of manganese oxide species for the formation of acrylamide (1,2-addtion), the strong basic sites of magnesium species probably at cation sites for the formations of 3-hydroxy-propionitrile and bis-2-cyano-ethylether (1,4-addition), and the third basic sites of magnesium species probably in the frameworks for the formation of succinonitrile. The selectivities of bis-2-cyano-ethylether and 3-hydroxy-propionitrile sequentially disappear and the selectivity of acrylamide increases with decreasing magnesium contents of Mg-todorokite by the acid-treatment. The sole product formed over Co-todorokite and Ni-todorokite catalysts is acrylamide because their basicity would be lower than those of $\mathrm{CoO}, \mathrm{NiO}$, and $\mathrm{Mg}$-todorokite catalysts. The order of the apparent activation energies is Co-todorokite $<\beta-\mathrm{MnO}_{2}<$ Ni-todorokite $<$ Mg-todorokite. The relatively low activation energy of Co-todorokite could be due to the moderate AOS of 3.8 and/or the interaction of cobalt species with manganese species. The relatively high activation energy of Mg-todorokite could be due to the difference in the product selectivity. These reactions are probably occurring on the extra surface of the todorokite catalysts because the micropores are occupied with water. If the micropores of todorokite are usable for the other catalytic reactions, the todorokite catalysts are expected to show the product shape-selectivity.

\section{Summary}

Todorokite-type manganese oxides containing cobalt (Co-todorokite) and nickel (Ni-todorokite) were synthesized from birnessite precursors containing cobalt and nickel prepared under $9.0 \mathrm{~mol} \mathrm{~L}^{-1}$ of $\mathrm{NaOH}$ and aged for $48 \mathrm{~h}$. These preparation conditions for birnessite precursors were higher concentration and longer time than the optimum conditions for the todorokite-type manganese oxide containing magnesium (Mg-todorokite). The Co-todorokite and Ni-todorokite have a degree of crystallinity as high as that of 
Mg-todorokite. Although the three samples contain both needle and platelet shaped crystallites, the proportions of needle to platelet and the crystal sizes increase with following order, Mg-todorokite > Ni-todorokite $>$ Co-todorokite.

The catalytic properties were investigated for the hydration of acrylonitrile. The apparent activation energies depend on the foreign metal elements as follows; Co-todorokite $\left(39 \mathrm{~kJ} \mathrm{~mol}^{-1}\right)<$ Ni-todorokite $(57 \mathrm{~kJ}$ $\mathrm{mol}^{-1}<\mathrm{Mg}$-todorokite $\left(104 \mathrm{~kJ} \mathrm{~mol}^{-1}\right)$. The high activity of Co-todorokite might be due to the moderate AOS of manganese being 3.8. The Mg-todorokite catalyst has three kinds of active sites which are weak basic manganese oxides for the formation of acrylamide (1,2-addtion), strong basic magnesium species probably at cation sites for 3-hydroxy-propionitrile and bis-2-cyano-ethylether (1,4-addition), and the third basic sites of magnesium species probably in the frameworks for the formation of succinonitrile. The sole product formed over Co-todorokite and Ni-todorokite catalysts is acrylamide, which could be due to the lower basicity than those of $\mathrm{CoO}, \mathrm{NiO}$, and $\mathrm{Mg}$-todorokite catalysts.

\section{References}

[1] S. Turner and P. R. Buseck, Science 212 (1981) 1024.

[2] S. L. Suib, Current Opinion in Solid State \& Materials Science 3 (1998) 63.

[3] J. E. Post, D. L. Bish, Am. Mineral. 73, (1988) 861.

[4] Q. Feng, H. Kanoh, K. Ooi, J. Mater. Chem. 9 (1999) 319.

[5] S. Ching, K.S. Krukowska, S. L. Suib, Inorg. Chim. Acta 294 (1999) 123.

[6] E. N. Tolentino, Z. R. Tian, H. Zhou, G. Xia, and S. L. Suib, Chem. Mater. 11(1999) 1733.

[7] J. Ostwald, Mineral. Mag. 50 (1986) 336.

[8] R. G. Burns and V. M. Burns, in Marine Manganese Deposites, Elsevier, Amsterdam, 1977.

[9] A. Usui, T. A. Mellin, M. Nohara, and M. Yuasa, Mar. Geol. 86 (1989) 41.

[10] D. C. Golden, C. C. Chen, and J. B. Dixon, Science 231, (1986) 717.

[11] Y. F. Shen, R. P. Zerger, R. N. DeGuzman, S. L. Suib, L. McCurdy, D. I. Potter, and C. L. O’Young, Science 260 (1993) 511.

[12] Y. F. Shen, S. L. Suib, and C. L. O’Young, J. Am. Chem. Soc. 116 (1994) 11020.

[13] Q. Feng, H. Kanoh, Y. Miyai, and K. Ooi, Chem. Mater. 7, (1995) 1722. 
[14] H. Kanoh, Y. Miyai, K. Ooi, Chem. Mater. 7 (1995) 1722.

[15] M. J. Duncan, F. Leroux, J. M. Corbertt, and L. F. Nazar, J. Electrochem. Soc. 145 (1998) 3746.

[16] Q. Feng, H. Kanoh, K. Ooi, M. Tani, Y. Nakacho, J. Electrochem. Soc. 141 (1994) L135.

[17] P. B. Weisz, J. Catal. 10 (1968) 407.

[18] Y. F. Shen, S. L. Suib, and C. L. O’Young, J. Catal. 161 (1996) 115.

[19] Y. C. Son, V. D. Makwana, A. R. Howell, and S. L. Suib, Angev. Che. Int, Ed. 40 (2001) 4280.

[20] H. Zhou, J. Y. Wang, X. Chen, C. L. O’Young, and S. L. Suib, Micropor. Mesopor. Mater. 21 (1998) 315.

[21] V. V. Krishnan, and S. L. Suib, J. Catal. 184 (1999) 305.

[22] K. A. Malinger, K. Laubernds, Y. C. Son, and S. L. Suib, Chem. Mater. 16 (2004) 4296.

[23] T. Miyake, K. Koike, I. Aoki, N. Murayama, M. Sano, Appl. Catal. A 288 (2005) 216.

[24] J. Y. Wang, G. G. Xia, Y. G. Yin, S. L. Suib, and C. L. O’Young, J. Catal. 176 (1998) 275.

[25] H. Zhou, Y. F. Shen, J. Y. Wang, X. Chen, C. L. O'Young, and S. L. Suib, J. Catal. 176(1998) 321.

[26] T. K. Katranas, A. C. Godelitsas, A. G. Vlessidis, N. P. Evmiridis, Micropor. Mesopor. Mater. 69 (2003) 165.

[27] A. J. Fatiadi, Synthesis (1976) 65.

[28] Y. Izumi, Catal. Today 33 (1997) 371-409.

[29] F. Nozaki, T. Sodesawa, and T. Yamamoto, J. Catal. 84, (1983) 267-269.

[30] I. Fukada, T. Muraishi, K. Ikeda, M. Tokumitsu, S. Yamamoto, Japan Patent Kokai, JP 07061958 (1995).

[31] Z. R. Tian, Y. G. Yin, S. L. Suib, C. L. O’Young, Chem. Mater. 9 (1997) 1126.

[32] F. A. Al-Sagheer, and M. I. Zaki, Micropor. Mesopor. Mater. 67 (2004) 43.

[33] E. Vileno, H. Zhou, Q. Zhang, S. L. Suib, D. R. Corbin, T. A. Koch, J. Catal., 187 (1999) 285.

[34] M. Frondel, Am. Mineral., 45 (1960) 1167. 


\section{Tables}

Table 1. Synthesis conditions of todorokite-type manganese oxides.

\begin{tabular}{|c|c|c|c|c|c|c|c|}
\hline \multirow[b]{2}{*}{ Samples } & \multicolumn{4}{|c|}{ Synthesis of Na-birnessite } & \multicolumn{2}{|c|}{ Ion-exchange ${ }^{b}$} & \multirow{2}{*}{$\begin{array}{c}\text { Hydrothermal treatment } \\
\text { treatment } \\
\mathrm{h}, \mathrm{K}\end{array}$} \\
\hline & $\frac{\overline{\mathrm{Mn}^{7+} / \mathrm{M}}}{\mathrm{mo}}$ & $\frac{\mathrm{Mn} / \mathrm{M}^{\mathrm{a}}}{\text { atio }}$ & $\begin{array}{l}\mathrm{NaOH} \\
\mathrm{mol} \mathrm{L}^{-1}\end{array}$ & $\begin{array}{c}\text { aging } \\
\mathrm{h}\end{array}$ & $\begin{array}{l}\mathrm{M}^{2+} \\
\mathrm{mol} \mathrm{L}^{-1}\end{array}$ & $\begin{array}{c}\text { treatment } \\
\mathrm{h}, \mathrm{K}\end{array}$ & \\
\hline Co-todorokite & 0.4 & 7.0 & 9.0 & 48 & 0.5 & 24,323 & 48,433 \\
\hline Ni-todorokite & 0.4 & 7.0 & 9.0 & 48 & 0.1 & 24,323 & 48,433 \\
\hline Mg-todorokite & 0.4 & 7.0 & 3.0 & 24 & 0.5 & 24,323 & 48,433 \\
\hline
\end{tabular}

a. $\mathrm{M}$ is $\mathrm{Co}, \mathrm{Ni}$, or $\mathrm{Mg}$.

b. The ion-exchange treatments were carried out in aqueous solution of $\mathrm{Co}^{2+}, \mathrm{Ni}^{2+}$, and $\mathrm{Mg}^{2+}$.

Table 2. Chemical composition of synthesized materials.

\begin{tabular}{|c|c|c|c|c|c|c|}
\hline \multirow[t]{2}{*}{ Sample } & \multicolumn{5}{|c|}{ Relative elemental composition / atomic ratio \% } & \multirow[t]{2}{*}{$\operatorname{AOS}^{\mathrm{a}}$} \\
\hline & $\mathrm{Na}$ & $\mathrm{Co}$ & $\mathrm{Ni}$ & $\mathrm{Mg}$ & $\mathrm{Mn}$ & \\
\hline $\mathrm{Na}-(\mathrm{Co})$-birnessite & 18 & 11 & n.d. & n.d. & 71 & 3.6 \\
\hline Na-(Ni)-birnessite & 18 & n.d. & 10 & n.d. & 72 & 3.5 \\
\hline $\mathrm{Na}$-(Mg)-birnessite & 17 & n.d. & n.d. & 10 & 73 & 3.5 \\
\hline Co-buserite & trace & 27 & n.d. & n.d. & 73 & 3.8 \\
\hline Ni-buserite & trace & n.d. & 20 & n.d. & 80 & 3.5 \\
\hline Mg-buserite & trace & n.d. & n.d. & 19 & 81 & 3.6 \\
\hline Co-todorokite & trace & 27 & n.d. & n.d. & 73 & 3.8 \\
\hline Ni-todorokite & trace & n.d. & 19 & n.d. & 81 & 3.6 \\
\hline
\end{tabular}


a. Average oxidation states of manganese.

n.d. not detected.

Table 3. The hydration of acrylonitrile ${ }^{\mathrm{a}}$ over todorokite samples and metal oxides.

\begin{tabular}{|c|c|c|c|c|c|c|}
\hline \multirow[b]{2}{*}{ Catalysts } & \multirow[b]{2}{*}{$\begin{array}{c}\text { Conversion } \\
\quad / \%\end{array}$} & \multicolumn{4}{|c|}{ Selectivity / mol \% } & \multirow[b]{2}{*}{$\begin{array}{l}\text { S.A. } \\
/ \mathrm{m}^{2} \mathrm{~g}^{-1}\end{array}$} \\
\hline & & acryloamide & $\begin{array}{l}\text { 3-hydroxy } \\
\text { propionitrile }\end{array}$ & succinonitrile & $\begin{array}{l}\text { bis-2-cyano } \\
\text { ethylether }\end{array}$ & \\
\hline no catalyst & 0.0 & n.d. & n.d. & n.d. & n.d & - \\
\hline Co-todorokite & 12.3 & 100 & 0.0 & 0.0 & 0.0 & 26 \\
\hline Ni-todorokite & 3.5 & 100 & 0.0 & 0.0 & 0.0 & 16 \\
\hline Mg-todorokite & 6.9 & 32 & 57 & 6 & 5 & 22 \\
\hline $\mathrm{MnO}_{2}{ }^{\mathrm{b}}$ & 1.9 & 100 & 0.0 & 0.0 & 0.0 & 2 \\
\hline $\mathrm{Mn}_{2} \mathrm{O}_{3}{ }^{\mathrm{b}}$ & 0.3 & 100 & 0.0 & 0.0 & 0.0 & 2 \\
\hline $\mathrm{Mn}_{3} \mathrm{O}_{4}{ }^{\mathrm{b}}$ & 1.0 & 100 & 0.0 & 0.0 & 0.0 & 8 \\
\hline $\mathrm{MnO}^{\mathrm{b}}$ & 0.7 & 23 & 77 & 0.0 & 0.0 & 2 \\
\hline $\mathrm{MgO}$ & 76 & 0.0 & 78 & 0.0 & 22 & 9 \\
\hline $\mathrm{NiO}^{\mathrm{b}}$ & 1.7 & 17 & 83 & 0.0 & 0.0 & 2 \\
\hline $\mathrm{CoO}$ & 3.2 & 30 & 70 & 0.0 & 0.0 & 5 \\
\hline
\end{tabular}

a. $50 \mathrm{mg}$ of catalyst and $3.0 \mathrm{ml}$ of $5.0 \mathrm{vol} . \%$ of acrylonitrile $(2.8 \mathrm{mmol})$ aqueous solution were added in the batch reactor. Reaction time and temperature were $3 \mathrm{~h}$ and $393 \mathrm{~K}$, respectively.

b. $100 \mathrm{mg}$ of catalyst.

Table 4. The hydration of acrylonitrile ${ }^{\mathrm{a}}$ over Mg-todorokite treated by $0.01 \mathrm{~mol} \mathrm{~L}^{-1}$ and $0.10 \mathrm{~mol} \mathrm{~L}^{-1}$ of acetic acid solution.

\begin{tabular}{|c|c|c|c|c|c|c|c|}
\hline \multirow{3}{*}{ Catalysts } & \multirow{3}{*}{$\begin{array}{c}\text { Conversion } \\
/ \% \\
\end{array}$} & \multicolumn{3}{|c|}{ Selectivity / mol \% } & \multirow{3}{*}{$\begin{array}{l}\text { bis-2-cyano } \\
\text { ethylether }\end{array}$} & \multirow{2}{*}{\multicolumn{2}{|c|}{$\begin{array}{l}\text { Elemental } \\
\text { composition } \\
\text { / atomic } \%\end{array}$}} \\
\hline & & \multirow[t]{2}{*}{ acryloamide } & \multirow{2}{*}{$\begin{array}{l}\text { 3-hydroxy } \\
\text { propionitrile }\end{array}$} & \multirow[t]{2}{*}{ succinonitrile } & & & \\
\hline & & & & & & $\overline{\mathrm{Mg}}$ & $\mathrm{Mn}$ \\
\hline Mg-todorokite & 6.9 & 32 & 57 & 6 & 5 & 20 & 80 \\
\hline $0.01 \mathrm{~mol} \mathrm{~L}^{-1}$ & 6.9 & 54 & 35 & 10 & 0.0 & 16 & 84 \\
\hline
\end{tabular}


a. $50 \mathrm{mg}$ of catalyst and $3 \mathrm{ml}$ of $5 \mathrm{vol} . \%$ of acrylonitrile $(2.8 \mathrm{mmol})$ aqueous solution were added in the batch reactor. Reaction time and temperature were $3 \mathrm{~h}$ and $393 \mathrm{~K}$, respectively.

\section{Figure captions and Scheme captions}

Figure 1. Synthesis schematic images of Mg-todorokite. (a) is a step of the preparation of birnessite materials by mixing the $\mathrm{A}$ and $\mathrm{B}$ solutions and by aging, (b) is a step of the ion exchange with $\mathrm{MgCl}_{2}$ solutions, and (c) is a step of the hydrothermal treatment.

Figure 2. XRD patterns of Mg-todorokite (a), Ni-todorokite (b), and Co-todorokite (c).

todorokite, $\mathrm{Mn}_{2} \mathrm{O}_{3}, *$ manganite $(\mathrm{MnOOH}), \times$ unknown phase.

Figure 3. SEM images of Mg-todorokite, Ni-todorokite, and Co-todorokite.

Figure 4. XRD patterns of (a) Mg-buserite, (b) Ni-buserite, and (c) Co-buserite. $\boldsymbol{\nabla}$ : buserite phase .

Figure 5. Effects of thermal treatments at $473 \mathrm{~K}$ on structures of todorokite (a) and buserite (b) samples.

Figure 6. Arrhenius plots for acrylonitrile hydration over Mg-todorokite $(\diamond)$, Ni-todorokite $(\boldsymbol{\square})$, and Co-todorokite $(\mathbf{\Delta})$.

Scheme 1. The hydration of acrylonitrile: 1, acrylonitrile; 2, acrylamide; 3, 3-hydroxy-propionitrile.

Scheme 2. Reaction scheme of the hydration of acrylonitrile. 


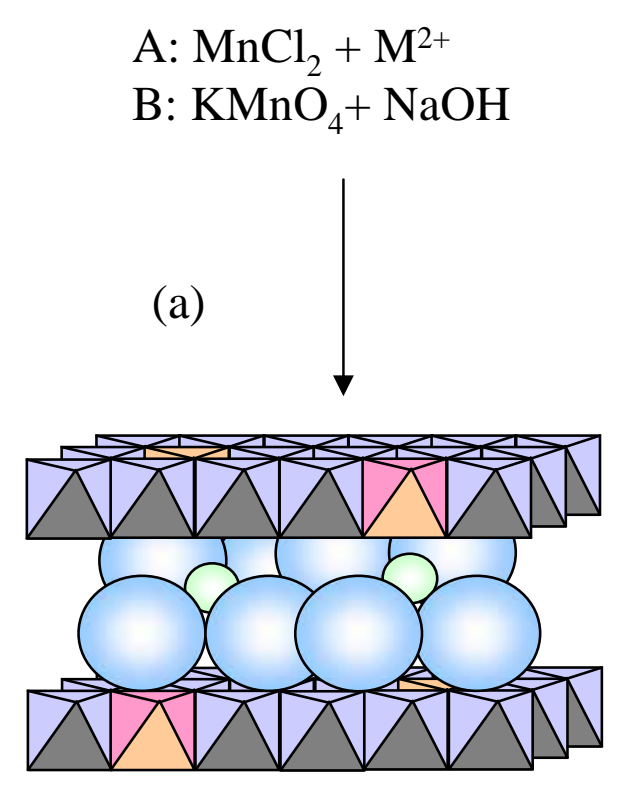

Na- (M) - birnessite

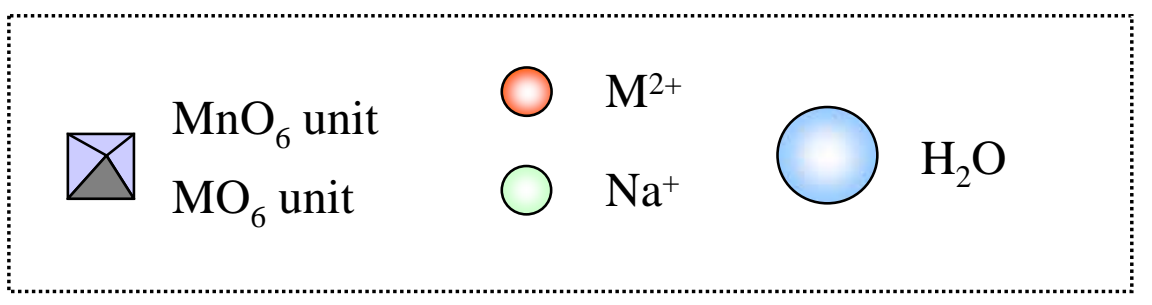

(b)
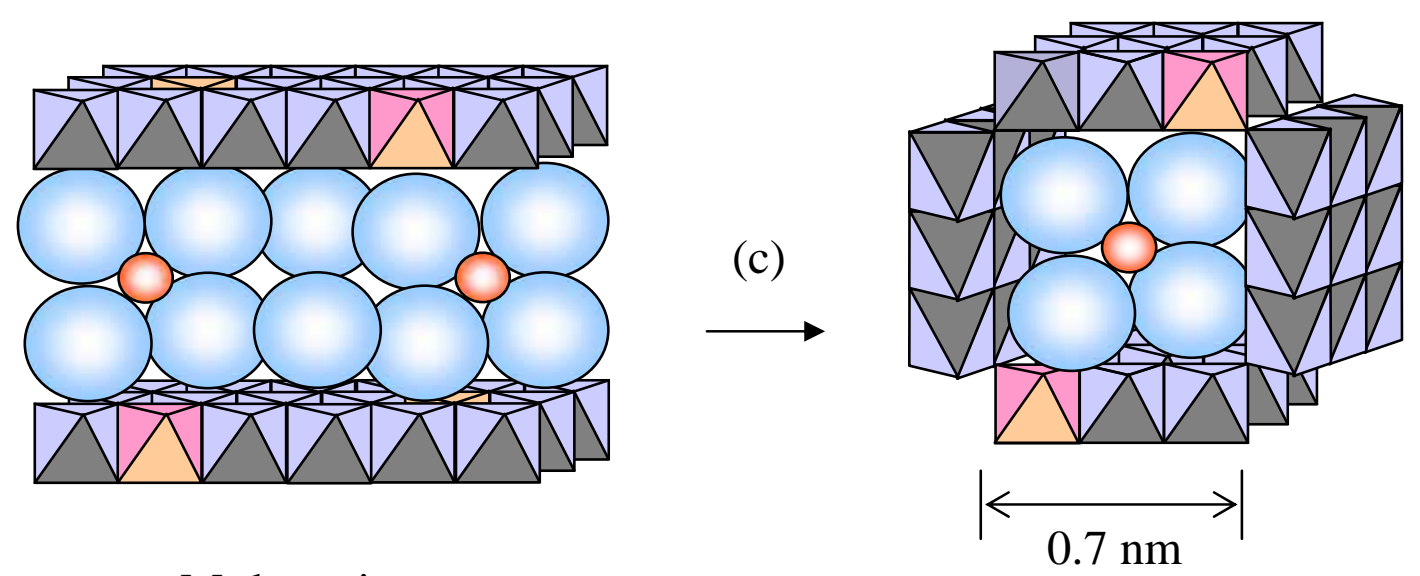

M- buserite (c)

M- todorokite

Figure 1. Synthesis schematic images of M-todorokite, where $\mathrm{M}$ represents a foreign metal cation. (a) is a step of the preparation of birnessite materials by mixing the A and B solutions and by aging, (b) is a step of the ion exchange with $\mathrm{M}^{2+}$ solutions, and (c) is a step of the hydrothermal treatment. 


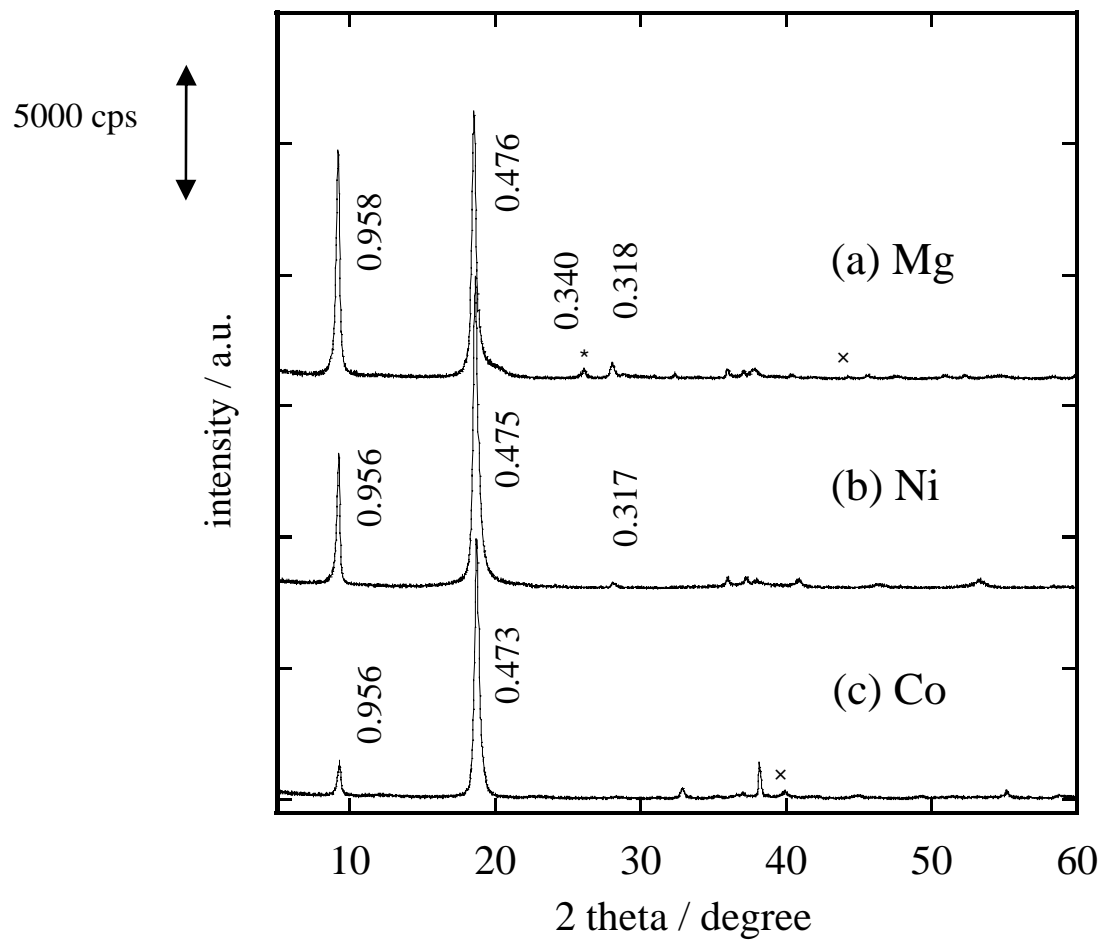

Figure 2. XRD patterns of Mg-todorokite, (b) Ni-todorokite, and (c) Co-todorokite. $\mathbf{\square}$ : todorokite, $\diamond: \mathrm{Mn}_{2} \mathrm{O}_{3}$, * : manganite $(\mathrm{MnOOH}), \times$ : unknown phase. 


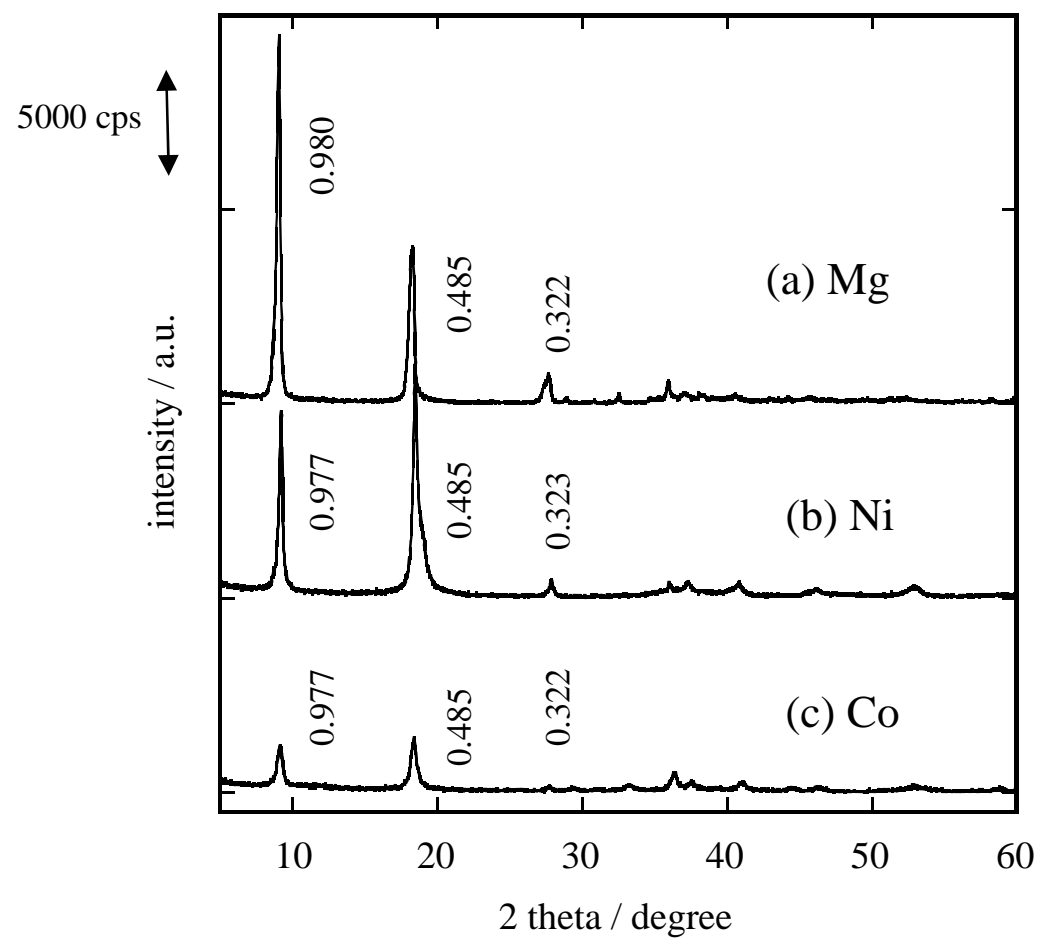

Figure 4. XRD patterns of (a) Mg-buserite, (b) Ni-buserite, and (c) Co-buserite. $\boldsymbol{\nabla}$ : buserite phase . 

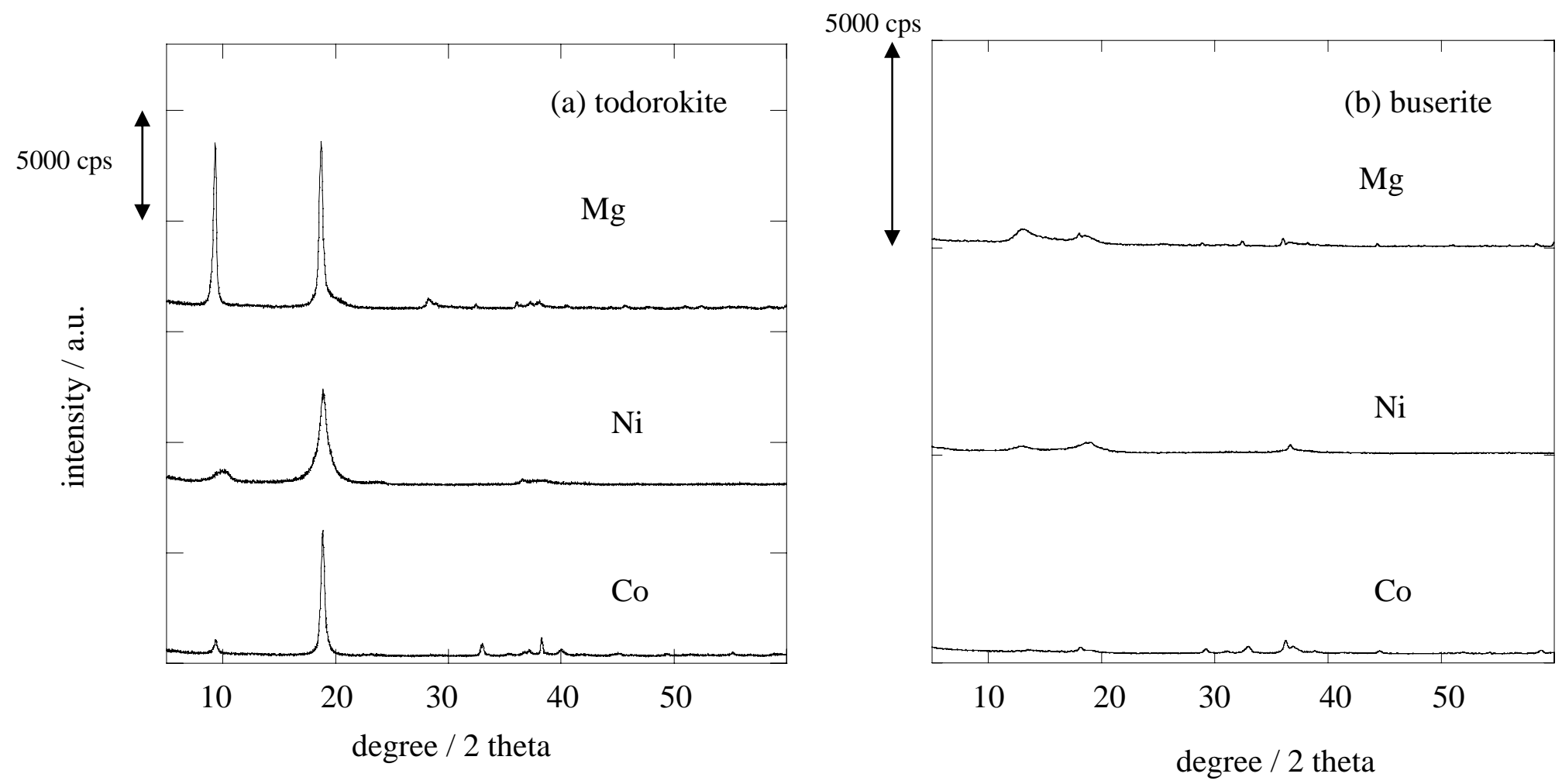

Figure 5. Effects of thermal treatments at $473 \mathrm{~K}$ on structures of todorokite (a) and buserite (b) samples. 


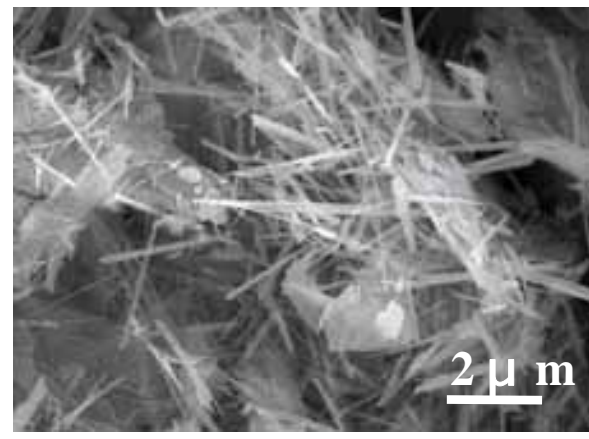

Mg-todorokite

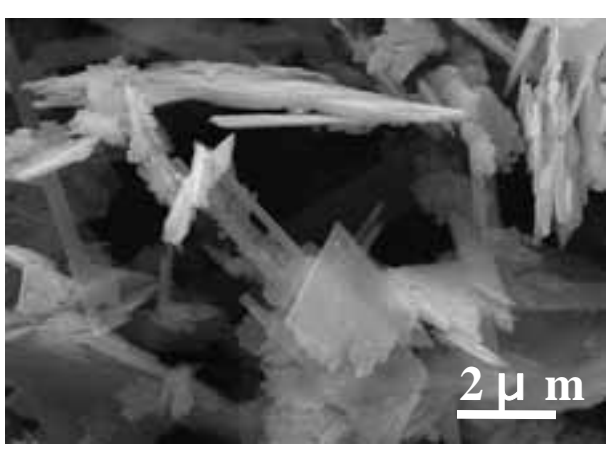

$\mathrm{Ni}$-todorokite

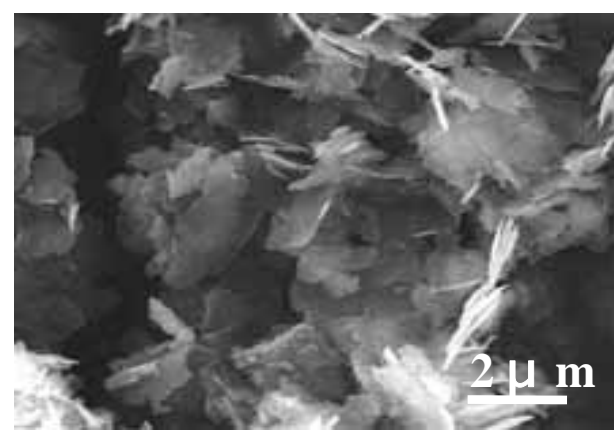

Co-todorokite

Figure 3. SEM images of Mg-todorokite, Ni-todorokite, and Co-todorokite. 


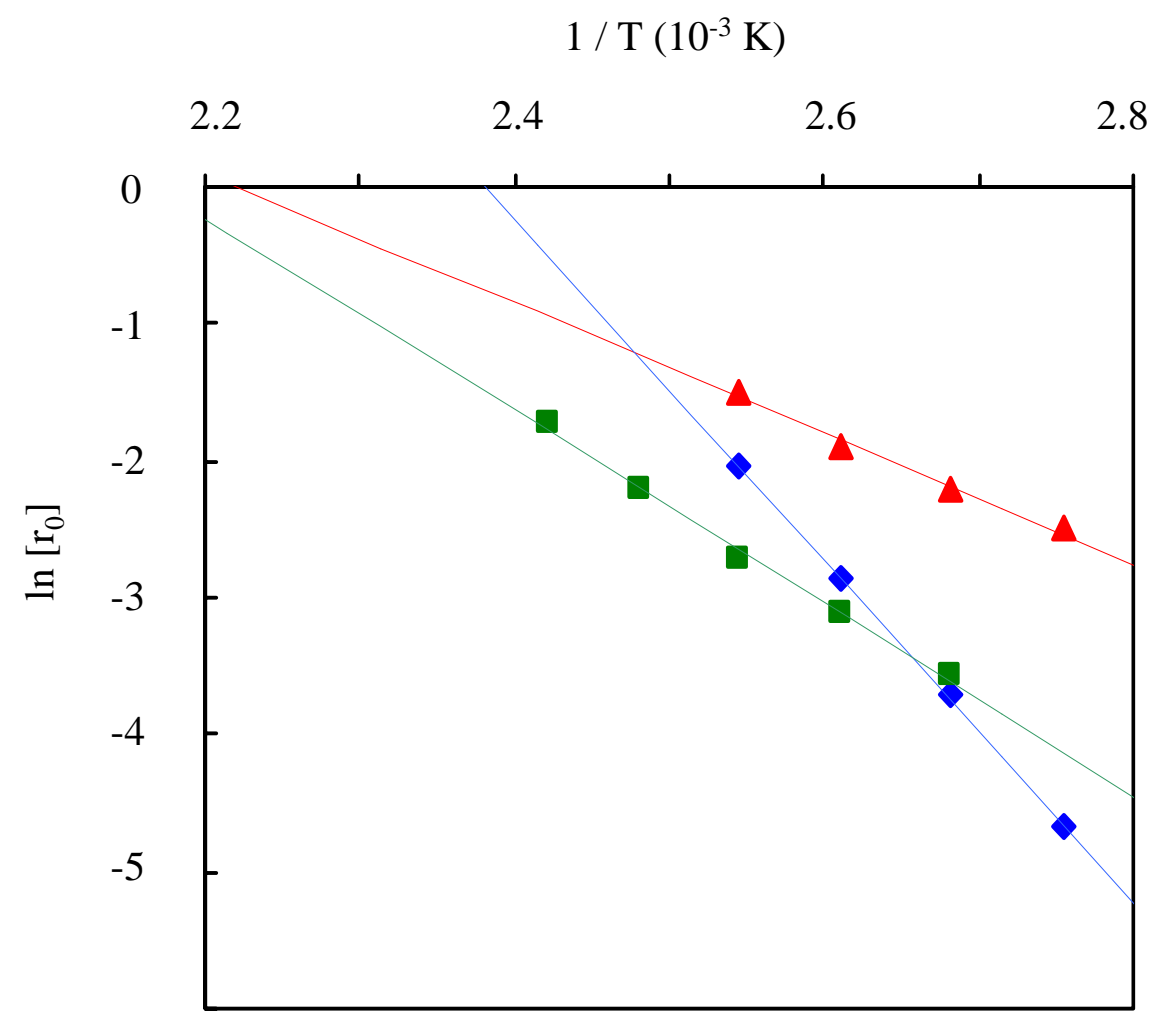

Figure 6. Arrhenius plots for acrylonitrile hydration over todorokite catalysts : $(\boldsymbol{)})$ : Mg-todorokite, ( $\mathbf{\square})$ : Ni-todorokite, $(\boldsymbol{\Delta})$ : Co-todorokite. 


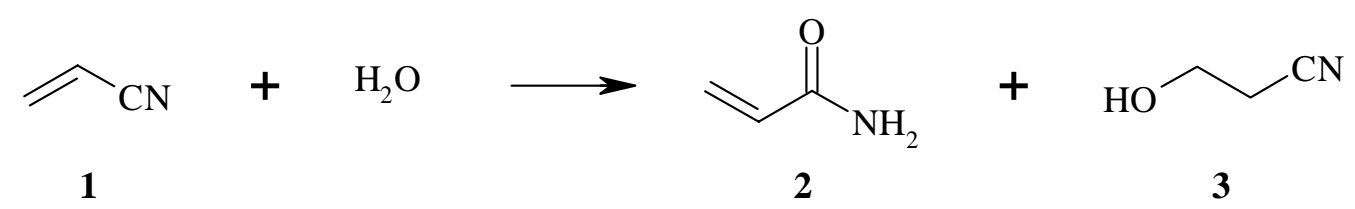

Scheme 1. The hydration of acrylonitrile: 1, acrylonitrile; 2 , acrylamide; 3 , 3-hydroxy-propionitrile. 


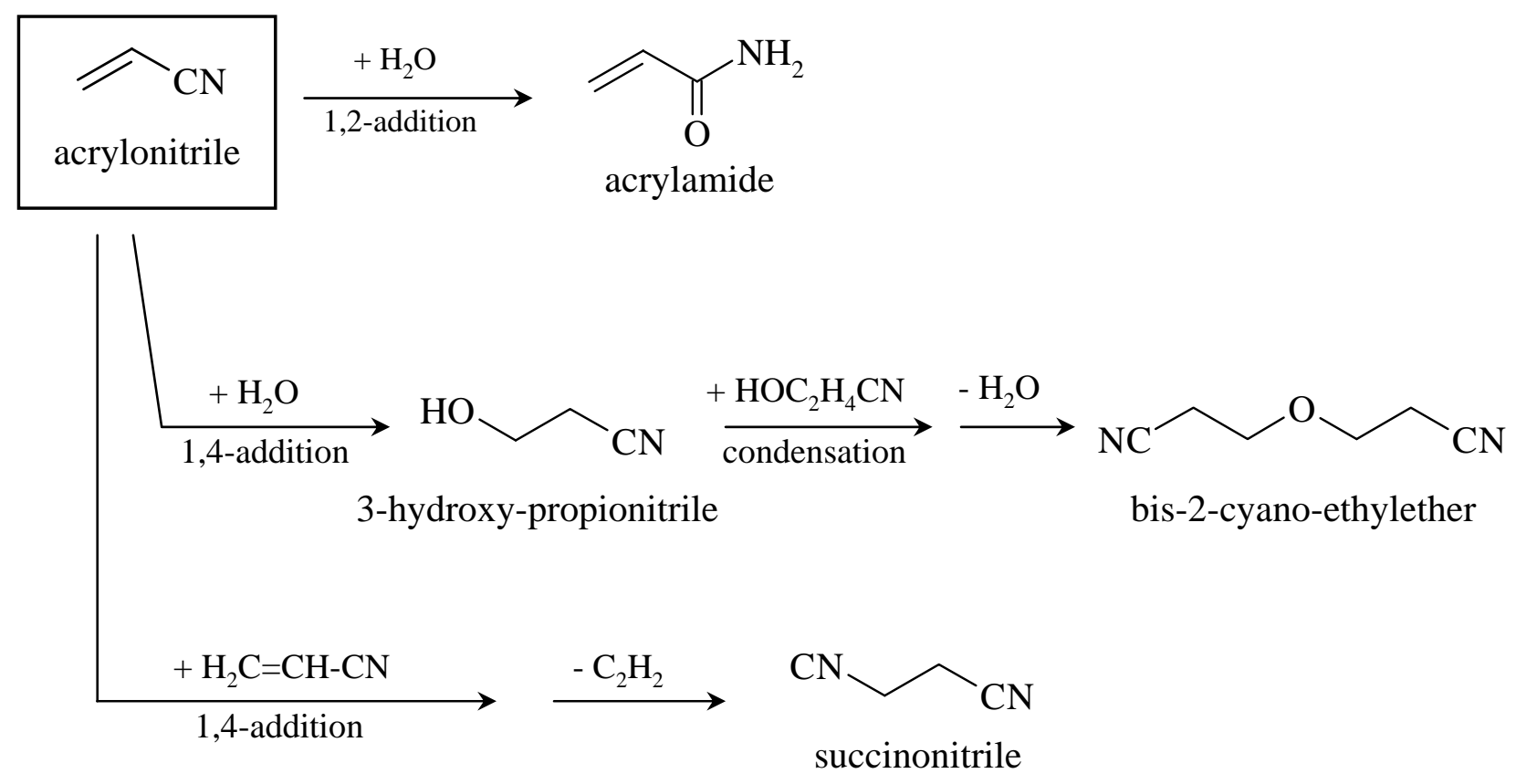

Scheme 2. Reaction scheme of the hydration of acrylonitrile. 